\title{
DEVELOPMENT OF LOW-COST ADDITIVE MANUFACTURING SYSTEM THROUGH SELECTIVE INHIBITION SINTERING (SIS) PROCESS AND EVALUATION OF MECHANICAL CHARACTERISTICS OF FABRICATED PARTS
}

\author{
Mesfin Sisay Mengesha*, Balasubramanian esakki, ArunkUMar \\ PONNAMBALAM, SILAMBARASAN MATHIYAZHAGAN AND RAJAMANI DEVARAJ \\ Centre for Autonomous System Research, \\ Vel Tech Rangarajan Dr. Sagunthala R\&D Institute of Science and Technology, \\ Chennai - 600062, India \\ "Corresponding author: mesfins245@gmail.com
}

(Received: $4^{\text {th }}$ February 2020; Accepted: $19^{\text {th }}$ May 2020; Published on-line: $4^{\text {th }}$ July 2020)

\begin{abstract}
Additive manufacturing (AM) is widely being used in today's contemporary industry; however, products fabricated by the existing AM techniques are costly due to the high machine cost and low production rate. Therefore, the focus of this work is to design and fabricate a cost-effective and novel powder based selective inhibition sintering (SIS) system. Various subsystems of the machine such as the infrared heater assembly, inhibition deposition mechanism, build and feed tank assemblies, powder deposition, and the compaction system have been indigenously designed and fabricated. An electronic control system is also established through integrating sensors, linear and rotary actuators, belt and pulley mechanism, and temperature feedback control unit. The customized SIS system is developed by integrating the assembly of all the subsystems, and the electronic modules with an open-source platform to generate the necessary motion characteristics. Besides, an open source RepRap user interface firmware has been used to control the machine. Thermo-structural finite element analysis has been used to study the sintering behaviour of powder material. Inhibitor material selection and preparation have been carried out by performing an experimental investigation on the inhibition effects of various materials. The machine has been tested through fabricating parts from HDPE polymer powder. Finally, the performance of the produced parts has been evaluated by conducting an experimental investigation. The results of the investigation indicated that the fabricated parts have attained sufficient mechanical strength and, hence, the developed SIS system can be utilized to manufacture functional parts.
\end{abstract}

ABSTRAK: Industri pembuatan bahan tambahan (AM) banyak digunakan dalam industri kontemporari semasa; walau bagaimanapun, produk yang terhasil daripada teknik sedia ada AM adalah mahal disebabkan harga mesin yang mahal dan kadar penghasilan yang rendah. Oleh itu, tujuan kajian ini adalah bagi mereka cipta serbuk baharu dengan harga berpatutan berdasarkan sistem pensinteran rencatan pilihan (SIS). Pelbagai mesin subsistem seperti pemasangan pemanas inframerah, mekanisme pemendapan rencatan, binaan dan pemasangan tangki suapan, deposisi serbuk, dan sistem pemadatan telah direka cipta secara alami dan dipasang siap. Sistem kawalan elektronik juga diadakan melalui integrasi sensor, lelurus dan penggerak putaran, jaluran dan mekanisme takal dan suhu unit kawalan suap balik. Sistem SIS yang dibuat mengikut pesanan ini dihasilkan dengan mengintegrasi pemasangan kesemua subsistem, dan modul elektronik melalui platfom sumber terbuka bagi menghasilkan ciri-ciri pergerakan bersesuaian. Selain itu, sumber terbuka RepRap perisian tegar antara muka telah digunakan bagi mengawal mesin. 
Analisis unsur terhingga struktur-terma digunakan bagi mempelajari perihal pensinteran bahan serbuk. Pilihan bahan perencat dan persediaan telah dijalankan dengan menjalankan siasatan eksperimen pada kesan perencat pelbagai bahan. Mesin diuji melalui pemasangan bahagian daripada HDPE serbuk polimer. Akhirnya, bahagian yang terhasil diuji melalui ujian eksperimen. Hasil kajian menunjukkan pemasangan bahagian telah mencapai kekuatan mekanikal mencukupi, dengan itu sistem SIS yang dibina boleh digunakan bagi mengilang bahagian berkaitan.

KEYWORDS: additive manufacturing; selective inhibition sintering; IR heater; tensile strength; flexural strength

\section{INTRODUCTION}

Additive manufacturing (AM) is a process that fabricates functional parts directly from three-dimensional (3D) computer-aided design (CAD) data through adhesion of materials layer-upon-layer as opposed to the subtractive methodology [1,2]. Because AM can manufacture any complex geometry in a short span of time, and production volume does not affect the cost of the fabricated part as it would in the case of the subtractive manufacturing method [3], it is widely being considered in today's contemporary industry. Moreover, unlike a traditional fabrication technique, the AM process does not require tooling such as jigs, fixtures, and cutters as well as coolants to operate [4]. Kurth et al. [5] classified the AM process based on the state of the raw materials used as solid, powder, and liquid based processes. Amongst these classifications, the Selective Inhibition Sintering (SIS) process, first invented by Khoshnevis et al. [6], at the University of Southern California, is a powder-based process that operates based on the principle of inhibiting a selected region from sintering to make a part [6-9]. SIS is a contemporary approach to Selective Laser Sintering (SLS) [10]. Unlike the SLS process, the SIS process uses a low cost infrared heat source instead of a high power laser. Hence, it is an economical powder based additive fabrication method that fabricates parts on a layer-upon-layer basis. Moreover, adaptability to various materials such as polymers, ceramics, and metals is another key advantage of the SLS and SIS processes. Unlike other AM manufacturing technologies, SLS and SIS do not require support material as the unsintered powder acts as support material.

The principal idea in the SIS system is to inhibit selected regions of powder layer from fusing using precise delivery of inhibitor material. The high melting point inhibitor material is deposited on the selected region of the powder bed to define the part profile and a ceramic heater is used to supply heat energy across the predetermined surface area of a layer. Due to the large difference between melting points of inhibitor and polymer powder, the region printed with inhibitor material will absorb heat energy and therefore be inhibited from sintering while the remaining area is sintered. Finally, the inhibitor and un-sintered powder can be washed away from the part after the building of the part is complete. As mentioned above, the major difference between the SLS and SIS processes are the heat sources and the sintering mechanisms. In addition, the SIS process has many advantages over the SLS processes. As a result of eliminating the high power heat source (the SIS system does not use high power lasers and cooling circuitry) the carbon footprint associated with SIS is much less compared to other laser enabled AM processes. Hence, compared to the existing 3D printing techniques, SIS will have a significantly less detrimental effect on the environment. It has a higher printing speed due to area sintering instead of point sintering as used in the SLS process. Moreover, similar to the SLS process, its adaptability to various materials such as polymers, ceramics, and metals is an important feature of the SIS process. Therefore, this fabrication technique can be implemented for processing a wide range of indigenously 
available polymer materials such as polypropylene, HDPE, LDPE, polycarbonates, and polystyrene $[6,9,11]$.

Since the invention of the first SIS system, improvements were done to the existing system in terms of adapting to metallic materials. Khoshnevis et al. [9] developed an Alpha selective inhibition sintering machine and characterized the process parameters of the machine by fabricating bronze parts and studying their quality features. In addition, Petros et al. [12] developed a $\beta$-SIS machine that fabricates metallic products. Torabi et al. [13] introduced an SIS metal machine that uses a commercial piezoelectric inkjet printer-head to deliver the inhibitor material. A bronze part was produced with the machine and the mechanical property of the fabricated part was investigated.

Some of the drawbacks of the existing SIS systems are: compaction related problems during the spreading of the powder layer, material wastage, and the presence of significantly large numbers of process variables that influence the quality characteristics of the fabricated parts [14]. Asiabanpour et al. [15] identified more than 30 factors that influence the SIS process. The presence of a large number of process parameters has complicated the optimization problem of identifying the best combinations of parameters and their settings. As a result, SIS process characterization has become a tedious task. Thus, improving the quality of the SIS fabricated part has become a cumbersome task and consequently, quality characteristics such as the mechanical properties, dimensional tolerance, and surface roughness of the SIS fabricated parts has been inferior [13]. Several research works were conducted to enhance the quality of the SIS fabricated part. Balasubramanian et al. [16] have optimized the settings of the few significant SIS process factors to improve the dry sliding wear behaviour of high-density polyethylene (HDPE). Baligidad et al. [17] studied and optimized SIS factors' settings that affect the dimensional accuracy of products. Yoozbashizadeh et al. [18] explored the effect of the inhibitor materials and the sintering phenomenon on the mechanical strength of SIS fabricated metallic parts. Rajamani et al. [19] investigated the influence of the SIS process variables on shrinkage characteristics of SIS parts. Optimization problem of SIS process was studied by various researchers. The effect of process variables on surface quality characteristics was examined by Rajamani et al [20]. As a result, impact of some process variables on part quality has been comprehended, and the result of the investigation showed that the mechanical, dimensional, and surface characteristics of the products are in acceptable ranges.

Despite the reports of the experimental studies, none of the aforementioned SIS systems are being utilized in the fabrication of functional parts. As a result, it is not commercialized and is not available in the additive manufacturing market yet. In addition, a design document for the fabrication of the SIS system has not been addressed sufficiently in the literature. However, with innovative design approach, it can be made applicable for fabricating prototypes and functional aircraft parts, UAV structures, automobile components, prosthetics, and exoskeleton devices. Thus, a new approach needs to be followed to design and develop an SIS system that eliminates the issue of the existing system.

Therefore, this work presents a comprehensive and systematic approach to the design and development of a low cost SIS system. The functionality of the developed machine has been tested by fabricating parts from HDPE polymer powder. The Polymer material used to fabricate the test specimens and prototypes has been chosen by examining the thermostructural behaviour of various polymers through finite element analysis. In addition, the inhibitor solution was selected by conducting multiple pilot tests on their inhibition and penetration effects. Finally, the produced parts were tested for tensile and flexural strength to evaluate their performance. In this paper, the detailed design of SIS subsystems such as 
the heater assembly, inhibition system, build and feed tanks, powder deposition, electronic control unit, and software and hardware integration are presented. Testing of developed SIS system and component fabrication is discussed. Furthermore, evaluation of the mechanical strength of the fabricated part was performed to determine the applicability of the developed system for fabricating useful products.

\section{MATERIALS AND METHODS}

\subsection{Selection of Inhibitor}

In the SIS process, the selected region of the powder layer is wetted through a liquid called an inhibitor which defines the part boundary. Inhibitor liquid is a saturated aqueous solution of high melting point salt with high water solubility $[7,10]$. Bhuvaneshwaran et al. [21] investigated a few of the salt materials as inhibition purposes. In order to reduce the surface tension of the aqueous solution, avoid the formation of droplets, and thereby achieve effective penetration into the powder layer, a small amount of isopropyl alcohol was mixed with the solution. As the amount of isopropyl alcohol added to the solution increases, salt gets precipitated [21]. Therefore, about $17 \%$ to $20 \%$ of alcohol was an optimum amount for $100 \mathrm{ml}$ of water to produce the desired effect.

Preliminary experiments were performed to evaluate the performance of each inhibitor material by applying heat energy on the polymer powder with an inhibitor at the periphery. It is observed that barium chloride $\left(\mathrm{BaCl}_{2}\right)$ and potassium iodide $(\mathrm{KI})$ produced less uniform penetration than other inhibitors, [21]. However, KI is preferable due to its high solubility to water which is essential for effective inhibition.

\subsection{Selection of Polymer}

In the present work, various polymer materials were considered as candidate materials for the SIS process, and the selection of specific polymers was carried out by evaluating their thermo-structural load carrying capacity using a finite element (FE) analysis. Figure 1 indicates the FE model of the powder bed and inhibitor solution. The polymer material and inhibitor material are represented in light grey and dark grey colours respectively. For the thermal analysis, $85 \%$ of the melting point of the polymer was used as input heat energy and the rate of heat transfer through the free surface is computed by assuming a free convection heat transfer coefficient, $\mathrm{h}=30 \mathrm{~W} / \mathrm{m}^{2} \mathrm{~K}$. Figure $2(\mathrm{a})$ and $2(\mathrm{~b})$ show the result of the FE analysis and it indicates the coupled effect of thermal as well as structural loads on a single sintered layer as temperature distribution is applied as an input to the structure assuming a fixed bottom polymer layer.

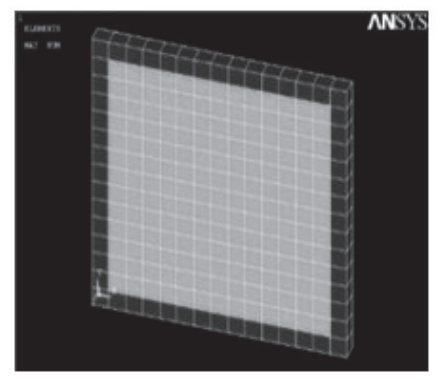

Fig. 1: FE model of polymer and inhibitor part. 


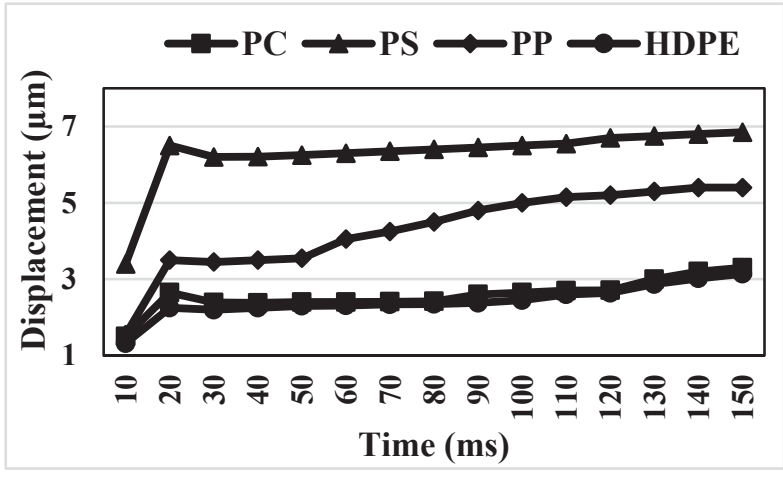

(a)

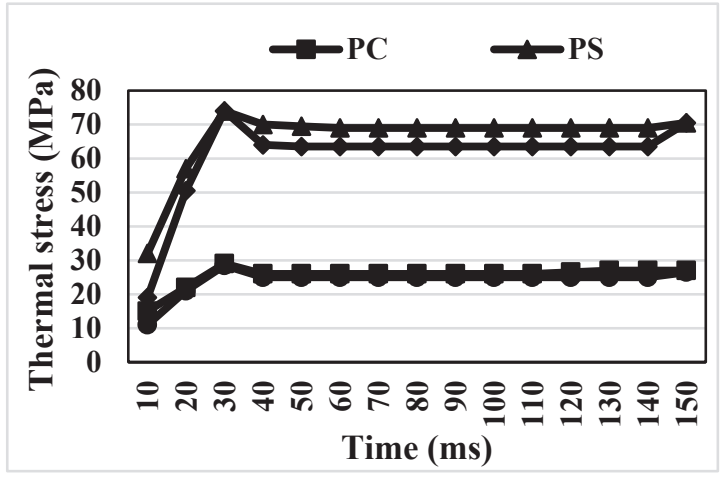

(b)

Fig. 2: (a) Displacement (b) Thermal stress of different polymer materials i) PP, ii) $P C$, iii) PS, iv) HDPE.

In comparison to other polymers, HDPE [22] attained minimal displacement and thermal stress as shown in Fig. 2(a) and Fig. 2(b) respectively, and hence it is considered for part fabrication.

\section{DESIGN AND DEVELOPMENT OF THE SELECTIVE INHIBITION SINTERING (SIS) SYSTEM}

The SIS system comprises the following sequence of operations to build functional parts layer by layer: How to use this document?

- Spread a thin layer of powder over the build tank from the feed tank

- Wet selected region of powder layer with inhibitor liquid to define the periphery of the part.

- Expose both the wetted and un-wetted powder layer to a heat source.

- Move down the build tank and simultaneously move up the feed tank through a small distance which defines layer thickness of the part.

- Spreading another layer of powder over the previously sintered layer.

- Repeat the process for each layer until the desired part is completed.

In order to attain the aforementioned operations, various subsystems such as build and feed tank assembly, powder deposition and compaction mechanism, inhibitor deposition, and heater assembly are indigenously designed and fabricated.

\subsection{Feed, Build and Collector Tank}

The SIS system is comprised of a feed and build tank. The feed tank is a reservoir that stores the powder material, and build tank is the platform where parts are constructed. These two platforms move vertically up and down in the opposite direction synchronously. When a build tank moves downward to a certain distance, the feed tank moves upward by the same distance equal to the desired layer thickness. In addition, a collector tank is provided to collect surplus powder during the powder deposition and compaction process. The platforms are made from high-grade aluminium plate machined to the required dimension using a water jet cutting process that provides precision and surface finish to avoid misalignments during assembly. A build tank of $200 \times 200 \times 200 \mathrm{~mm}$, a feed tank of $250 \times 200 \times 200 \mathrm{~mm}$ and a collector tank of $50 \times 200 \mathrm{~mm}$ is designed as shown in Fig. 3. 


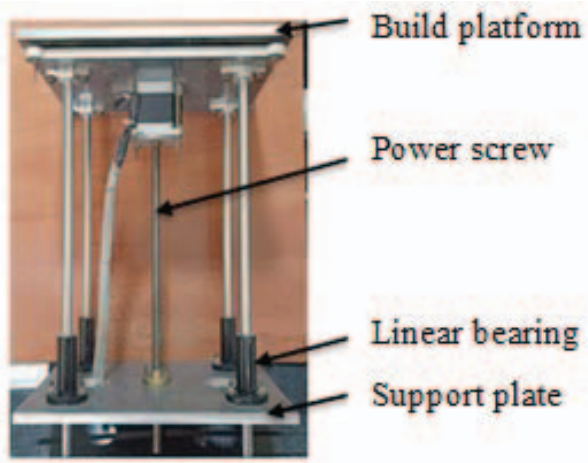

Fig. 3: Feed and build platforms assembly.

The upward and downward movement of the two tanks is achieved through a power screw driven by NEMA-23 stepper motors. Four round steel bars are used to guide the bedplates of both tanks in their upward and downward motions. The movement of the feed and build tank is designed so that the required amount of powder is made available in order to deposit a powder layer thickness with the required layer thickness. The possible swaying of the top plate as it moves vertically up and down is eliminated with the help of linear bearings fitted at the bottom of the tanks as shown in Fig. 3.

\subsection{Powder Spreading and Compaction System}

A simple mechanism (Fig. 4) that deposits a layer of powder on the build platform and compresses it to the required level of density is designed and fabricated. It is made up of a blade and a round bar. In order to reduce the number of voids and increase density, the powder bed requires compression using a roller. The blade spreads the powder on the build platform and the roller follows the blade to compact the powder bed to the required density. Hence, a round bar follows the blade during powder layer preparation.

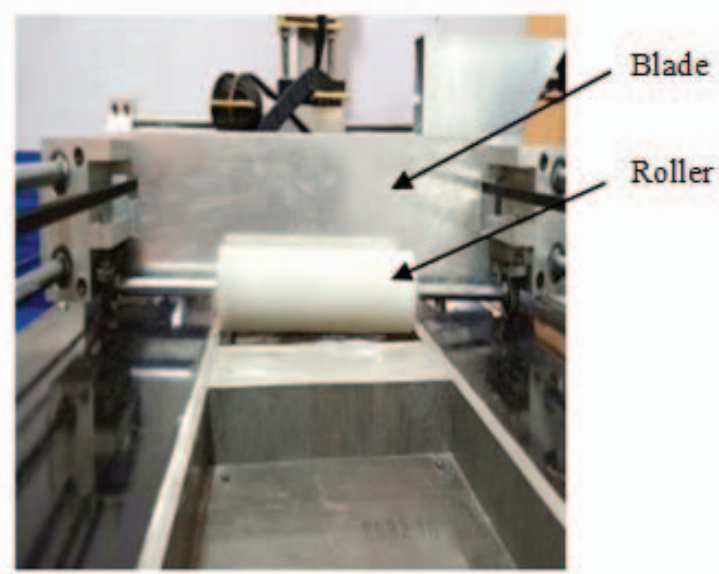

Fig. 4: Powder feeding and compacting mechanism.

The height of the roller from the build platform determines the layer thickness of parts. Therefore, depending on the strength required from the final sintered part, the height of the spreader-roller needs to be varied. As a result, the height of the spreader-roller is designed to be adjustable. In addition, the lower edge of the blade (spreader) is positioned slightly above the roller to ensure that a sufficient amount of material is provided for achieving the desired part density. 


\subsection{Inhibitor Deposition System}

The inhibitor deposition mechanism consists of a syringe, a linear lead screw, and a stepper motor (Fig. 5). The stepper motor is used to drive the plunger linearly in a reciprocating manner. The rotational motion of the stepper motor is converted into a reciprocating motion of the plunger (piston) to compress the inhibitor solution through the nozzle. Two round steel bars are used to avoid sidewise swaying of the plunger thereby it moves perpendicular to the cross-sectional area of the syringe barrel without the piston head pushing the inner wall of the barrel. This enables the mechanism to deposit inhibitor solution efficiently on the powder layer. The designed inhibitor deposition system has a capacity of $60 \mathrm{ml}$ of inhibitor and a plastic dispensing tip of $0.4 \mathrm{~mm}$ nozzle diameter [8] was used.

The flow rate of the inhibitor is influenced by the actuator's power (speed and torque). Droplet size is controlled through fitting cheap dispensing tips at the tip of the syringe. Multiple iterations were carried out to obtain an optimum printer feed rate. This mechanism is a low cost mechanism, yet it is able to dispense inhibitor solution as desired.

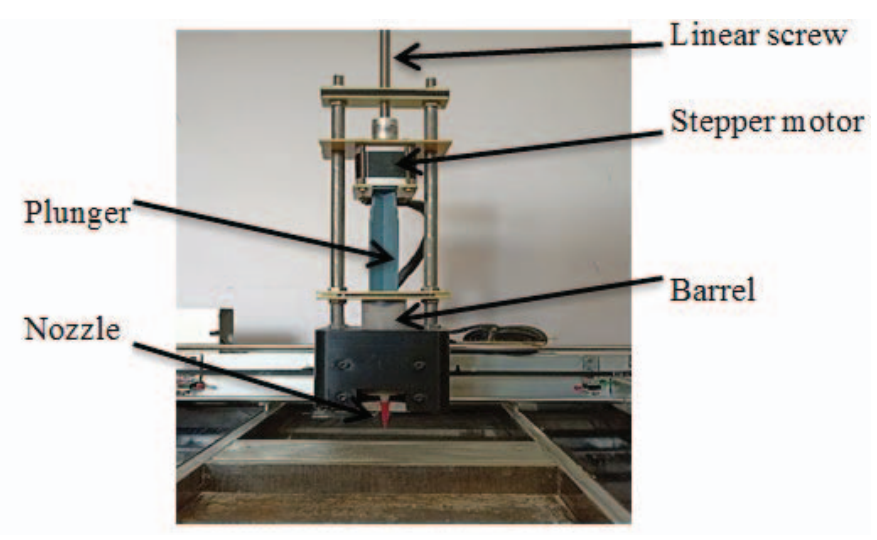

Fig. 5: Inhibitor deposition mechanism.

\subsection{Heater Assembly}

A short-wave infrared heater is used as a heat source for sintering the powder bed. The heat energy is transmitted from the source to the powder layer through electromagnetic radiation. The heating element, shown in Fig. 6, is made up of two lamps, each with 1000Watt / 240-Volt. The lamps are fixed to a casing that is constructed from aluminium sheet metal because aluminium has better reflectivity property of infrared light and strength to weight ratio. During the sintering process, the heat source moves in a single-axis ( $\mathrm{Y}$-axis) over the build tank at the required speed. In addition, a $150 \mathrm{~mm} \times 150 \mathrm{~mm}$ flat mica heater bed heater of 150-Watt / 230-Volt is fitted beneath the build tank.

Therefore, part wrapping during sintering is prevented by preheating the build platform with the bed heater to a temperature of approximately $90{ }^{\circ} \mathrm{C}-100{ }^{\circ} \mathrm{C}$ during and prior to depositing the powder layer.

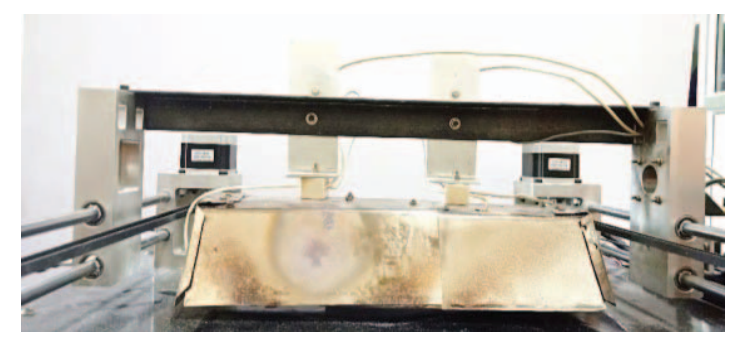

Fig. 6: Heating element. 


\subsection{X-Y Positioning Mechanism}

The $\mathrm{X}-\mathrm{Y}$ positioning system used in this machine is an $\mathrm{H}$-Bot that uses a low cost single timing belt to guide and position the cart on which the inhibitor depositor is attached as shown in Fig. 7(a). Two low-priced NEMA-17 stepper motors are used to actuate the X-Y micro positioning mechanism. The motor mount blocks on which the actuators are fitted and the cart that hold the nozzle are also machined from low cost aluminium. Round stainless steel bars are used as a guide for the moving elements of the mechanism.

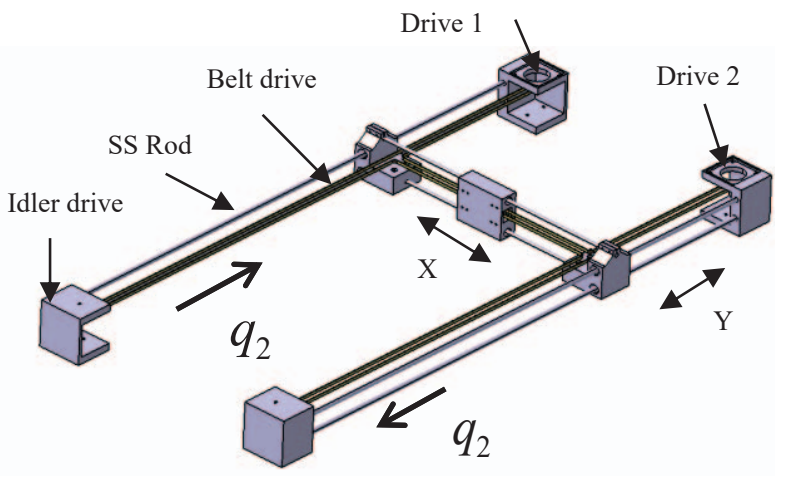

(a)

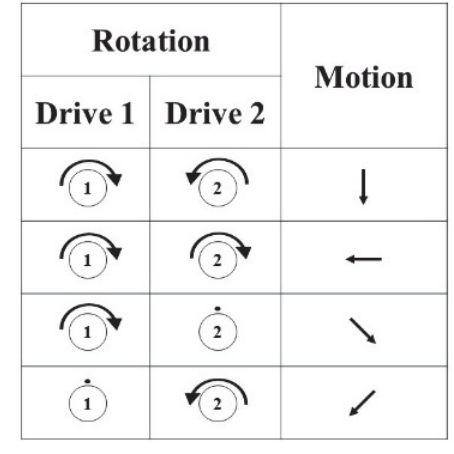

(b)

Fig. 7: X-Y positioning mechanism.

All elements of the mechanism except the belt and the stainless-steel rods are made of Al6061 and is fabricated using a CNC milling process. In this mechanism, fixed rotary drivers are connected by a single H-bar GT-2 timing belt of width $6 \mathrm{~mm}$ via GT-2 timing pulley. As indicated in Fig.7 (a), (b), the coordinated motion of the drive motors helps the mechanism to achieve the required movement. That is the nozzle of the inhibitor depositor mechanism can be moved along the required direction (X, Y, and combination of $\mathrm{X}$ and $\mathrm{Y}$ ), by controlling the motion of the drives. As can be seen from the figures, when motor 1 and motor 2 rotates in the counter-clockwise direction by $q_{1}$ and $q_{2}$ angles respectively, the angles $q_{1}$ and $q_{2}$ are shared by the linear displacement $x$ and $y$. Equation (1) and (2) below show the relationship of $q_{1}$ and $q_{2}$ with $x$ and $y$ distance movement of the nozzle.

$$
\begin{aligned}
& q_{1}=\Delta x+\Delta y \quad \text { and } \quad q_{2}=\Delta x-\Delta y \\
& \Delta x=\frac{1}{2}\left(q_{1}+q_{2}\right) \quad \text { and } \quad \Delta y=\frac{1}{2}\left(q_{1}-q_{2}\right)
\end{aligned}
$$

Therefore, when both drives rotate in the clockwise direction, the nozzle moves along the negative $\mathrm{X}$ direction. However, when they rotate counter-clockwise, the nozzle makes a positive $\mathrm{X}$-axis movement. Similarly, when one of the motors rotates in clockwise and the other rotates in the opposite direction, the nozzle moves along Y-axis. The rotation of a single drive enables the nozzle to move diagonally in the X-Y plane. Therefore, this mechanism can precisely position the nozzle at any point in $\mathrm{X}-\mathrm{Y}$ plane over the build platform.

\subsection{Base Structure}

The base structure that supports the entire setup of the SIS machine is required to be strong, tough and rigid as the kinematics of the system cannot be compromised. Most of the relatively heavy components are made from aluminium 6061 and the top support sheet is 
made from mild steel. In addition, stainless steel rods are chosen to support and guide the inhibition mechanism, the heating element, and the powder spreader and compactor mechanism. Hence, the beam and column of the machine are loaded with the lumped weight of all the components that is approximately $35 \mathrm{~kg}$.

The aluminium extrusion profile is chosen for the frame of the support structure as it is a lightweight and good corrosion-resistant material. It is also easy and economical to fabricate a structure from aluminium extrusion profiles than plastics or steel structures. Moreover, T-Slot aluminium profiles have high specific density than a steel structure. Hence, an aluminium extruded profile $(30 \mathrm{~mm} \times 30 \mathrm{~mm}$ ) frame is chosen for the support structure to provide structural rigidity to the machine.

\subsection{Hardware and Software Integration}

Customized design of the hardware (Fig. 8) showing all the connection of the actuators, sensors and control unit is created using the Proteus platform. The circuit shown in the figure is divided into two major categories as direct and alternating current circuits. The direct current circuit is the electronic controller that guides the computer-controlled SIS system to achieve desired characteristics.

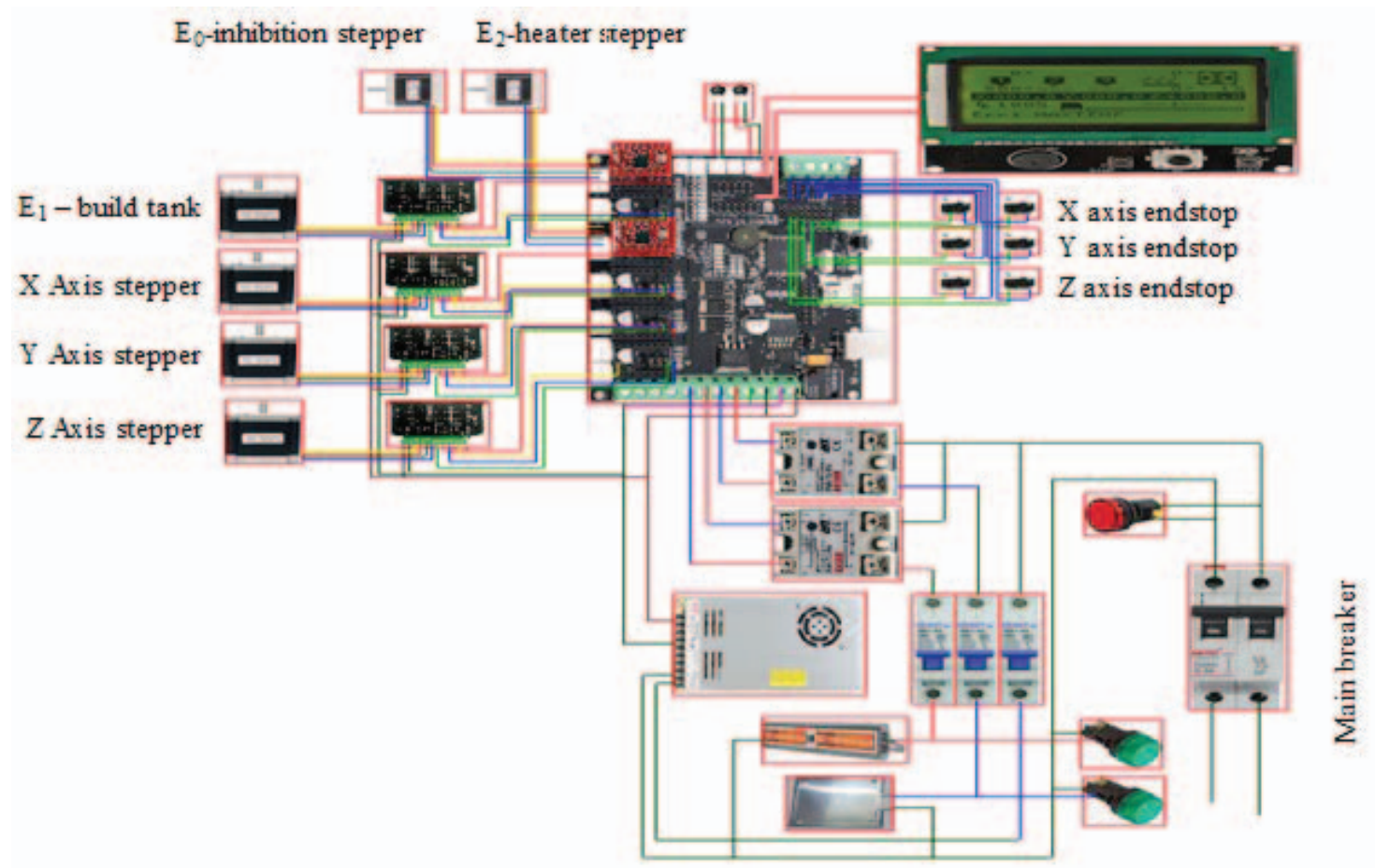

Fig. 8: Electronic control circuit.

A Megatronics V3.1 microcontroller is used to control the six stepper drivers (X, Y, Z, Extruder 1, Extruder 2 and Extruder 3) and the two heaters (Bed and IR heater). An input of $12 \mathrm{~V}$ power is delivered to the controller board via the $30 \mathrm{~A}$ switch mode power supply. The stepper drivers are designed to control the independent motions of the following components of the developed system: Powder deposition-compression mechanism (Y), nozzle motions ( $\mathrm{X}$ and $\mathrm{Y}$ ), feed tank ( $\mathrm{Z}$ ), inhibitor deposition mechanism (Extruder 1), liner movement of build tank (Extruder 2) and motion of IR heater (Extruder 3).

NEMA-23 stepper motors are used to drive X, Y, Z linear motions and Extruder 2 as they require relatively high torque motors. On the other hand, Extruder 1 and Extruder 3 are 
driven using NEMA-17 stepper motor. A4988 and Tb6600 stepper drivers are used to drive the NEMA-17 and NEMA-23 stepper motors respectively. In addition, the X and Y axis travel limits are controlled using micromechanical end stops. The control system of the heating elements is a closed-loop, and the output temperature of the infrared heater and bed heater is measured using $100 \mathrm{k}$ thermistors and $\mathrm{K}$ type thermocouple temperature sensors respectively. The microcontroller controls the temperatures through an SSR-25 solid state relay.

Software was developed by customizing an open-source Marlin firmware program based on the number and types of input and output devices of the developed machine and was uploaded to the Megatronics V3.1 microcontroller. Part fabrication using the developed system begins with creating the 3D CAD model of the required part in STL format. The CAD model then sliced into desired layer thickness using Slic3r software, and corresponding G - Codes are generated. Finally, based on the generated G-codes, Pronterface software is used to generate a numerical control (NC) machine tool path.

\subsection{Assembly of SIS Subsystems and Development of SIS System}

The designed subsystems such as build and feed tanks assembly, powder deposition and compaction mechanism, inhibition deposition mechanism and heater assembly are assembled to make the SIS system which is shown in Fig. 9. Preliminary testing on linear and rotary actuators, tanks assemblies, NC tool path generation, inhibitor deposition, heater motion, temperature feedback controller and limit switch sensing is performed.

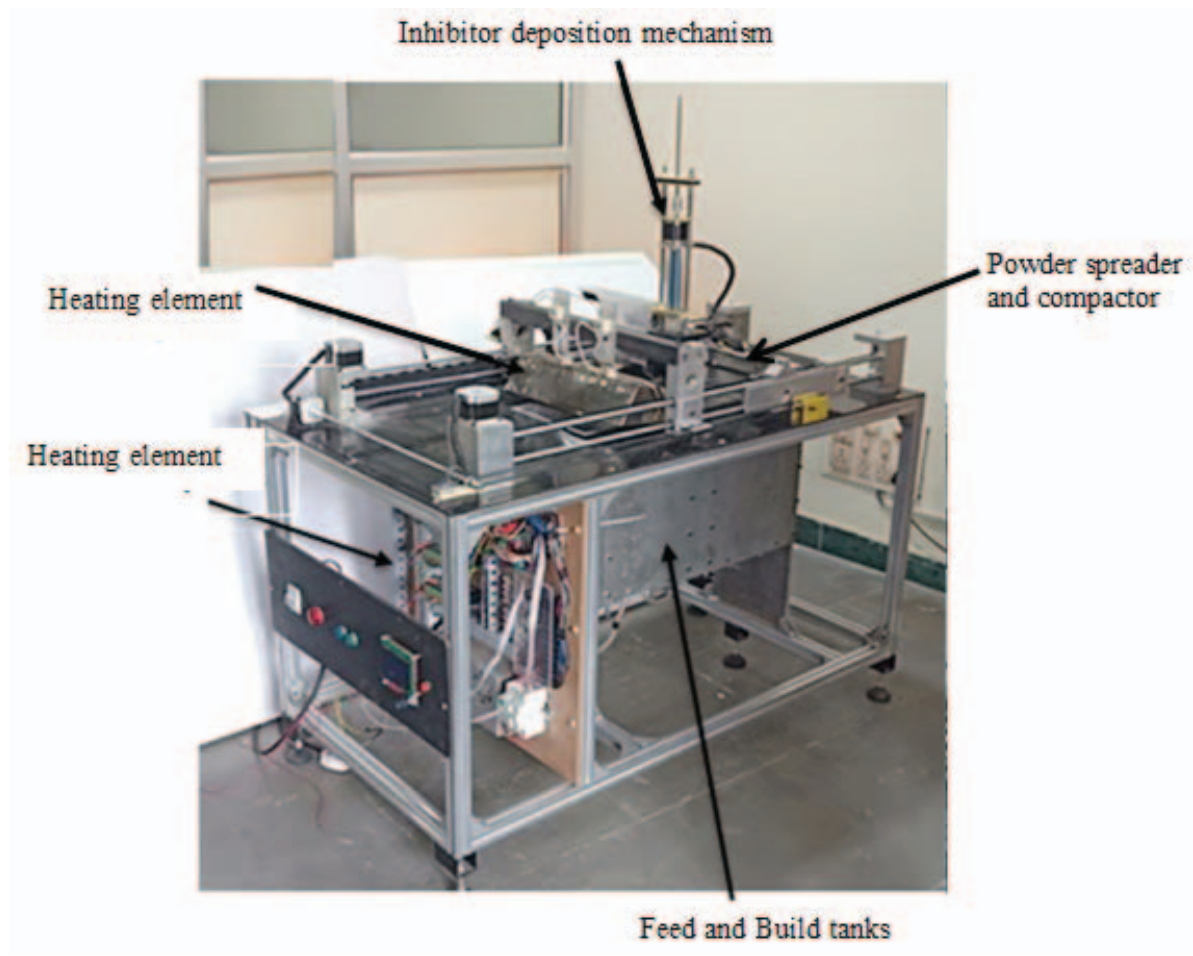

Fig. 9: Developed SIS system.

To minimize the cost of the SIS system, selection of temperature sensors, linear actuators, and belt drive systems are carried out with due consideration of cost-effectiveness and superior performance. A novel inhibition delivery mechanism is developed for the precise delivery of inhibitor. The composition of inhibitor material preparation was crucial to obtain precise inhibition effect on the polymer powder surface and is successfully achieved. The 
low-cost SIS system is developed by assembling the various components. The preliminary functionality tests demonstrate that the developed SIS system is applicable in all aspects and it can be used to produce functional parts. However, one major limitations of the developed SIS system is material wastage. In the SIS part fabrication process the entire powder bed is heated by the infrared heater which fuses the whole powder layer except the region that is wetted by the inhibitor solution. Consequently, the powder that is not in the waste powder is not reusable. In this developed system the powder bed region that make up the part body as well as the region outside the part cross sectional area is sintered which causes powder loss.

\subsection{Mechanical Strength Testing of SIS Fabricated Parts}

To evaluate the performance of the developed system and determine the influence of its process parameters such as heater feed rate, printer feed rate, layer thickness, and heat energy on the tensile and flexural strength of the fabricated part, sample parts were fabricated and their mechanical characteristics have been assessed. Specimens were fabricated from high-density polyethylene (HDPE) polymer powder, supplied by JP Polymers, India. As per the datasheet of the supplier, the grain size of the selected powder particles was in the range of $35 \mu \mathrm{m}$ to $80 \mu \mathrm{m}$. The powder used was $100 \%$ virgin so that any possible irregularities in the sintered parts were avoided. Box-Behnken based RSM approach was followed to perform an optimal set of experiments through varying SIS process parameters $[20,23]$. The process parameters were varied with three levels as indicated in Table 1.

Table 1: SIS process parameters and levels

\begin{tabular}{cccccc}
\hline S. No. & Parameters & Units & \multicolumn{3}{c}{ Levels } \\
\cline { 4 - 6 } & & & Low & Medium & High \\
\hline 1 & Layer thickness & $\mathrm{mm}$ & 1 & 2 & 3 \\
2 & Heat energy & $\mathrm{J} / \mathrm{mm}^{2}$ & 25.32 & 28.48 & 30.06 \\
3 & Heater feed rate & $\mathrm{mm} / \mathrm{sec}$ & 3 & 3.25 & 3.5 \\
4 & Printer feed rate & $\mathrm{mm} / \mathrm{min}$ & 100 & 110 & 120 \\
\hline
\end{tabular}

The range of settings for the considered process variables were determined based on the thermal property of the polymer powder by conducting numerous preliminary tests.

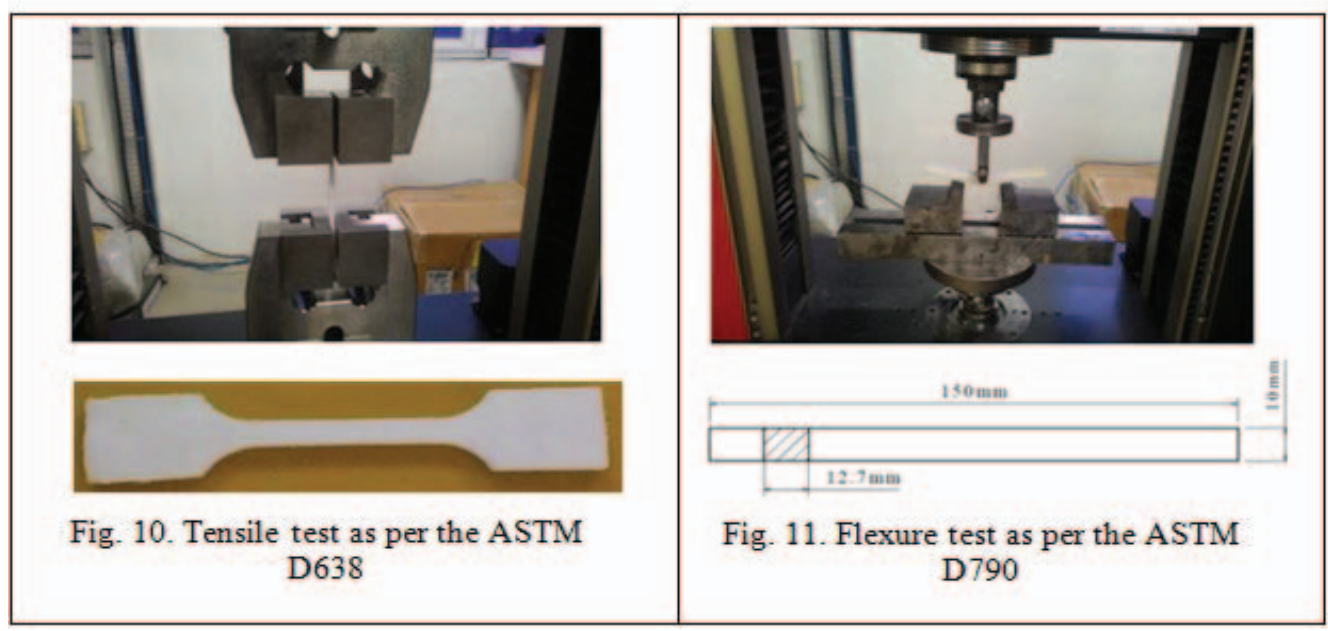


The tensile strength test was performed according to the ASTM D638 standard [24] with a test speed of $5 \mathrm{~mm} / \mathrm{min}$ at room temperature and $40 \%$ relative humidity. Similarly, the flexural strength test was carried out based on ASTM: D790 [25] standard with a test speed of 1.2 to $1.8 \mathrm{~mm} / \mathrm{min}$. The Instron 3369 dual column universal testing system shown in Fig. 10 and 11 were employed to carry out both tensile and flexure strength test.

\section{RESULTS AND DISCUSSION}

The result of the experiment and the combinations of corresponding parameters and their settings are given in Table 2 .

Table 2: Experimental results of tensile and flexural strengths

\begin{tabular}{|c|c|c|c|c|c|c|}
\hline Run & $\begin{array}{c}\text { Layer } \\
\text { thickness } \\
(\mathbf{m m})\end{array}$ & $\begin{array}{c}\text { Heat } \\
\text { energy } \\
\left(\mathrm{J} / \mathbf{m m}^{2}\right)\end{array}$ & $\begin{array}{c}\text { Heater feed } \\
\text { rate } \\
(\mathrm{mm} / \mathrm{s})\end{array}$ & $\begin{array}{l}\text { Printer } \\
\text { feed rate } \\
(\mathrm{mm} / \mathrm{min})\end{array}$ & $\begin{array}{c}\text { Tensile } \\
\text { strength } \\
\text { (MPa) }\end{array}$ & $\begin{array}{c}\text { Flexure } \\
\text { strength } \\
\text { (MPa) }\end{array}$ \\
\hline 1 & 3 & 28.48 & 3.5 & 110 & 23.05 & 25.46 \\
\hline 2 & 2 & 30.06 & 3 & 110 & 21.29 & 26.64 \\
\hline 3 & 1 & 28.48 & 3.5 & 110 & 22.53 & 26.34 \\
\hline 4 & 2 & 28.48 & 3.25 & 110 & 25.55 & 28.63 \\
\hline 5 & 3 & 25.32 & 3.25 & 100 & 24.39 & 26.35 \\
\hline 6 & 1 & 28.48 & 3.25 & 120 & 24.94 & 27.18 \\
\hline 7 & 2 & 30.06 & 3.5 & 120 & 20.53 & 24.20 \\
\hline 8 & 2 & 28.48 & 3 & 120 & 20.41 & 24.11 \\
\hline 9 & 2 & 30.06 & 3.5 & 110 & 25.92 & 27.57 \\
\hline 10 & 2 & 28.48 & 3.25 & 110 & 25.12 & 28.55 \\
\hline 11 & 2 & 30.06 & 3.25 & 100 & 24.64 & 28.13 \\
\hline 12 & 2 & 25.32 & 3.5 & 100 & 23.97 & 27.90 \\
\hline 13 & 3 & 28.48 & 3 & 110 & 20.86 & 26.18 \\
\hline 14 & 2 & 25.32 & 3.25 & 120 & 21.29 & 27.04 \\
\hline 15 & 2 & 25.32 & 3.5 & 110 & 19.34 & 25.24 \\
\hline 16 & 3 & 25.32 & 3.25 & 110 & 23.77 & 28.57 \\
\hline 17 & 2 & 28.48 & 3.25 & 110 & 24.29 & 27.22 \\
\hline 18 & 1 & 28.48 & 3 & 110 & 25.87 & 29.60 \\
\hline 19 & 2 & 28.48 & 3.5 & 100 & 21.62 & 26.40 \\
\hline 20 & 2 & 30.06 & 3.25 & 110 & 24.90 & 28.22 \\
\hline 21 & 2 & 28.48 & 3.25 & 110 & 24.70 & 22.10 \\
\hline 22 & 2 & 25.32 & 3 & 100 & 24.97 & 28.05 \\
\hline 23 & 2 & 30.06 & 3.5 & 120 & 25.25 & 28.19 \\
\hline 24 & 1 & 30.06 & 3.25 & 100 & 24.85 & 27.11 \\
\hline 25 & 1 & 28.48 & 3.25 & 110 & 26.54 & 32.08 \\
\hline 26 & 1 & 25.32 & 3.25 & 110 & 23.80 & 27.01 \\
\hline 27 & 3 & 30.06 & 3.25 & 110 & 24.97 & 28.94 \\
\hline 28 & 2 & 25.32 & 3 & 110 & 24.47 & 28.71 \\
\hline 29 & 3 & 28.48 & 3.25 & 120 & 22.90 & 26.77 \\
\hline
\end{tabular}

From the result of the experiments, it is evident that maximum tensile strength and flexural strength of $26.54 \mathrm{MPa}$ and $32.08 \mathrm{MPa}$ respectively were obtained for process 
variables settings: layer thickness of $1 \mathrm{~mm}$, heat energy of $28.48 \mathrm{~J} / \mathrm{mm}^{2}$, printer feed rate of $110 \mathrm{~mm} / \mathrm{min}$ and heater feed rate of $3.25 \mathrm{~mm} / \mathrm{sec}$.

The influence of input process parameters such as layer thickness, heat energy, heater feed rate and printer feed rate on tensile and flexure strengths were analysed as depicted in Fig. 12 and 13. The effect of each process parameter was distinctly analysed where other parameters were set at their mid-levels.
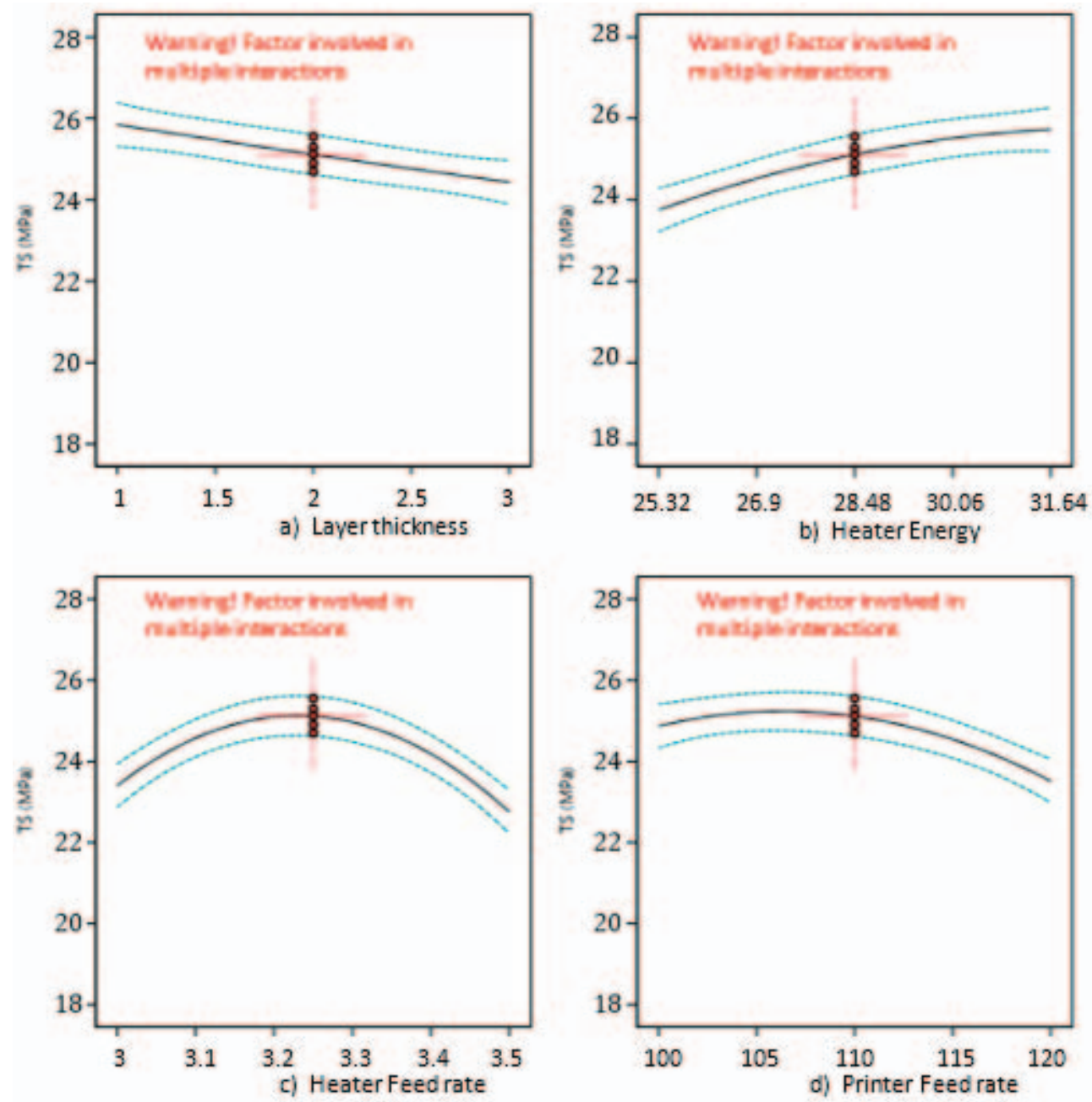

Fig. 12: Effect of process parameters on tensile strength of SIS parts.

As can be seen from Fig. 12 (a) and 13 (a) an increase in layer thickness leads to a reduction in tensile and flexural strengths. This is because at minimal layer thickness the bonding between successive layers is stronger. On the contrary, at maximum thickness of the powder layer, micro voids are developed which leads to the reduction of tensile strength [26]. Heat energy in the range of $27 \mathrm{~J} / \mathrm{mm}^{2}-31 \mathrm{~J} / \mathrm{mm}^{2}$, which is about $77 \%$ to $85 \%$ of the energy required to achieve the melting point of HDPE has resulted in a more compact structure due to better fusion of powder particles. Strong intermolecular attraction between the polymer particles occurs in the specified range of temperature. As a result, mechanical strength increased with an increase of heat energy as shown in Fig. 12 (b) and 13 (b) [27]. Therefore, heat energy necessary to bring strong bonding between powder particles helps to achieve high mechanical strength on the fabricated part. 
Furthermore, the effect of the heater feed rate as shown in Fig. 12 (c) and 13 (c), and printer feed rate indicated in Fig. 12 (d) and 13 (d) on the mechanical strength is nonlinear. As seen from the graphs mechanical strength increases up to the optimal value of the heater feed rate and printer feed rate which then decreases drastically. An increase in heater feed rate causes porosity between layers which diminishes the mechanical strength. The printer feed rate influences the inhibition penetration effect, which affects the dimensional and geometric characteristics of the part.
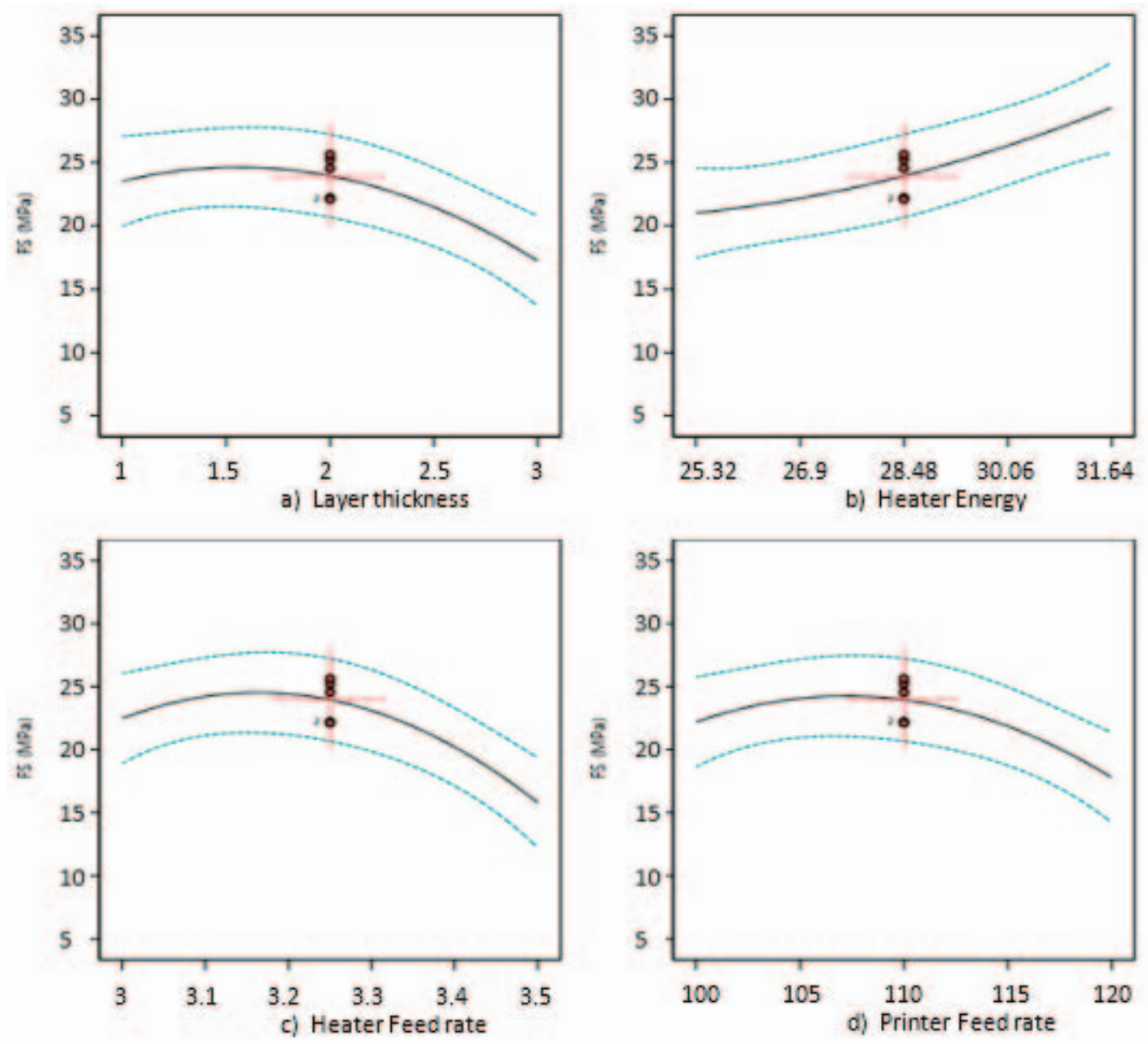

Fig. 13: Effect of process parameters on flexure strength of SIS parts.

Figure $14(\mathrm{a}-\mathrm{c})$ shows the SEM images of the fractured surface of the tensile test specimens fabricated with a heat energy of $28.48 \mathrm{~J} / \mathrm{mm}^{2}$. Analysis of the SEM images showed some porosity in the fractured surface. These voids act as stress concentrators and cause uneven distribution of the normal stress over the cross-sectional area of the test specimens. Therefore, such pores and voids observed need to be eliminated by optimizing the compaction pressure during layer making.

Figure 15 (a-c) shows the SEM micrograph of the flexural fractured surface of the specimens fabricated with heat energy of $28.48 \mathrm{~J} / \mathrm{mm} 2$. It is evident from Fig. 15 (a) that there is interphase de-lamination at the cross-section of the sintered specimen due to the applied flexural load. Voids are also observed in Fig. 15 (b) due to poor interfacial bonding between sintered particles. However, the formation of voids and uneven sintering of 
polymer particles are comparatively higher in the case of specimens fabricated below the applied heat energy of $28.48 \mathrm{~J} / \mathrm{mm}^{2}$.
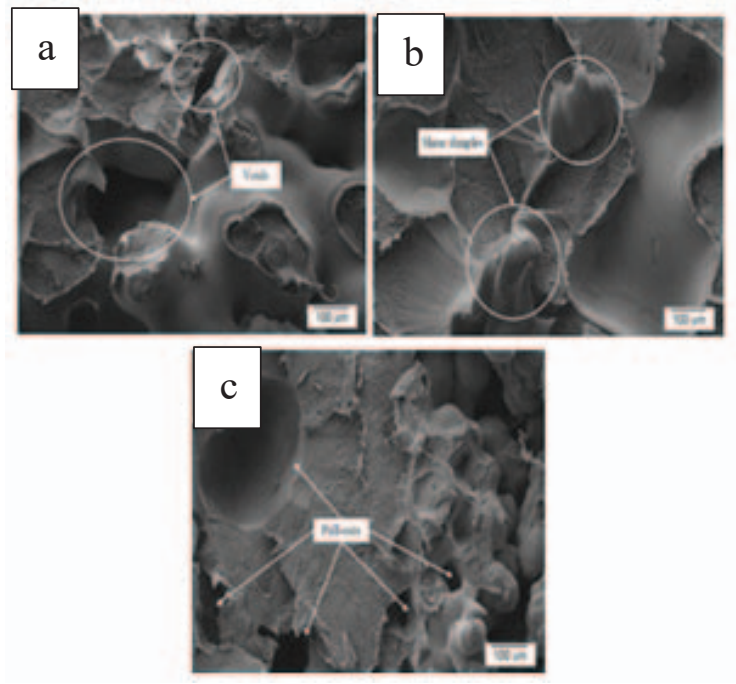

Fig. 14: Fractured surfaces of SIS fabricated tensile test specimen.
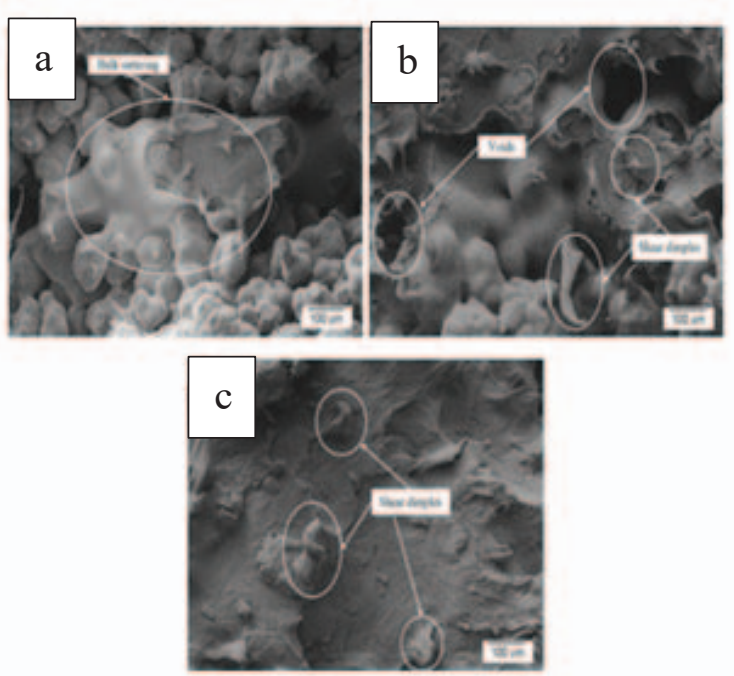

Fig. 15: Fractured surfaces of SIS fabricated flexural test specimen.

An identical load was constantly applied on the specimens' surface that created a shear band along the middle section of the specimens resulting in its breakage as seen in Fig. 15 (c). In addition, elongated dimples normal to the loading axis are observed in Fig. 15 (c). Moreover, few voids and bulk cohesion of particles are seen in the fractured surface, these can be attributed to the non-uniform heat distribution during sintering.

Response surface methodology (RSM) has been used for the optimization of mechanical strength characteristics as it handles the interaction effects of input parameters [28]. In order to validate the results obtained, confirmation experimental tests were conducted as shown in Table 3.

Table 3: Validation table

a) Comparison of predicted tensile strength with experiment result

\begin{tabular}{ccccccc}
\hline $\begin{array}{c}\text { Layer } \\
\text { thickness } \\
(\mathbf{m m})\end{array}$ & $\begin{array}{c}\text { Heat energy } \\
\left(\mathbf{J} / \mathbf{m m}^{\mathbf{2}}\right)\end{array}$ & $\begin{array}{c}\text { Heater } \\
\text { feed rate } \\
(\mathbf{m m} / \mathbf{s})\end{array}$ & $\begin{array}{c}\text { Printer feed } \\
\text { rate } \\
(\mathbf{m m} / \mathbf{m i n})\end{array}$ & $\begin{array}{c}\text { Predicted } \\
\text { value } \\
(\mathbf{M P a})\end{array}$ & $\begin{array}{c}\text { Experimental } \\
\text { value } \\
(\mathbf{M P a})\end{array}$ & $\begin{array}{c}\text { Error } \\
\text { percentage }\end{array}$ \\
\hline 1 & 28.48 & 3.2 & 110 & 27.21 & 27.80 & $2.12 \%$ \\
\hline
\end{tabular}

b) Comparison of predicted flexural strength with experiment result

\begin{tabular}{ccccccc}
\hline $\begin{array}{c}\text { Layer } \\
\text { thickness } \\
(\mathbf{m m})\end{array}$ & $\begin{array}{c}\text { Heat energy } \\
\left(\mathbf{J} / \mathbf{m m}^{\mathbf{2}}\right)\end{array}$ & $\begin{array}{c}\text { Heater } \\
\text { feed rate } \\
(\mathbf{m m} / \mathbf{s})\end{array}$ & $\begin{array}{c}\text { Printer feed } \\
\text { rate } \\
(\mathbf{m m} / \mathbf{m i n})\end{array}$ & $\begin{array}{c}\text { Predicted } \\
\text { value } \\
(\mathbf{M P a})\end{array}$ & $\begin{array}{c}\text { Experimental } \\
\text { value } \\
(\mathbf{M P a})\end{array}$ & $\begin{array}{c}\text { Error } \\
\text { percentage }\end{array}$ \\
\hline 1 & 28.48 & 3.2 & 110 & 33.60 & 34.59 & $2.86 \%$ \\
\hline
\end{tabular}

As can be seen from the table, the deviation of the actual tensile strength and flexural strength values from the predicted values are only by $2.12 \%$ and $2.86 \%$ respectively. Hence, it can be concluded that the predicted value is in good agreement with the experimental value. In addition, to evaluate the dimensional accuracy and geometric complexity of the 
parts fabricated using the developed low cost SIS system; sample components shown in (Fig. 16) were manufactured. These samples have shown dimensional accuracy of about 1 $\mathrm{mm}$ which shows that the developed system has the capability of producing parts with acceptable mechanical strength as well as dimensional accuracy.

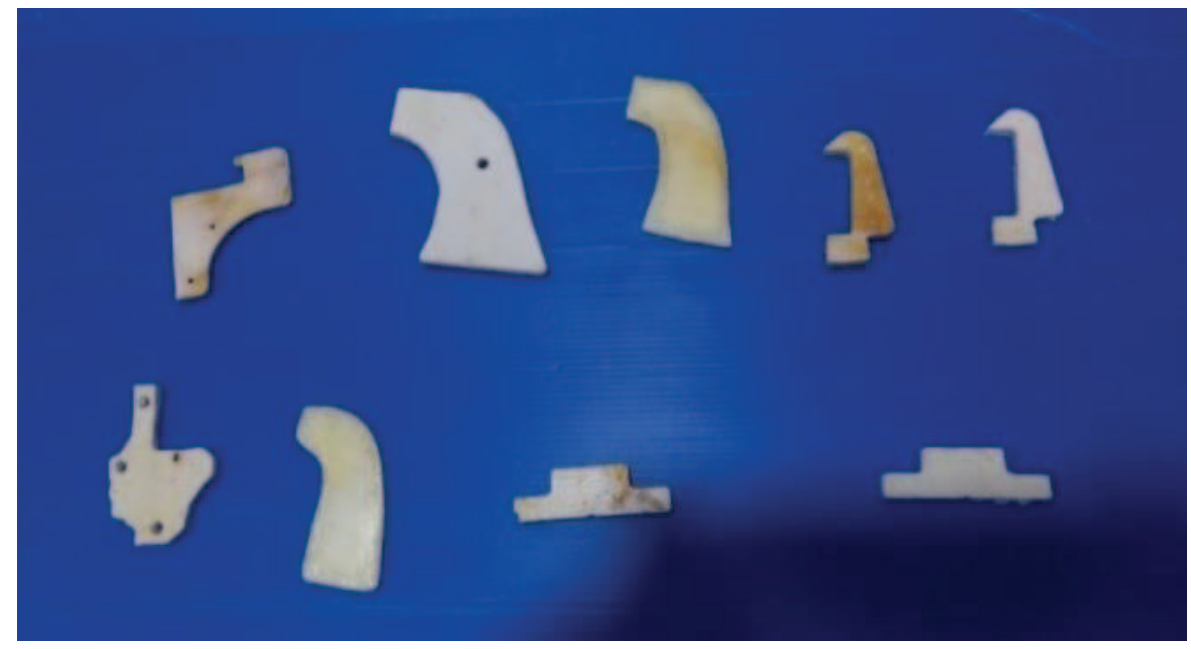

Fig. 16: Fabricated SIS parts.

Therefore, parts fabricated by the developed SIS system can be utilized as load carrying structural machine elements replacing components fabricated using another fabrication processes such as SLS and injection moulding.

\section{CONCLUSION}

The developed SIS system is custom-built through the integration of an indigenously designed $\mathrm{H}-\mathrm{Bot} \mathrm{X}-\mathrm{Y}$ precision position mechanism, inhibition depositor, heating element and build and feed tank assemblies. To minimize the cost of the SIS system, selection of temperature sensors, linear actuators, and belt drive systems are carried out with due consideration of cost-effectiveness and superior performance. A novel inhibition delivery mechanism that minimizes the controllable process variables has been developed and implemented for the precise delivery of inhibitor. In addition, an innovative low cost powder spreader was used, and thus the cost of the current machine has been brought down significantly so that it is economically affordable. The capability of the machine was tested by fabricating various parts from polymer powder, and the mechanical and geometric characteristics of the fabricated parts were evaluated. The polymer materials used to test the performance of the developed system were selected by evaluating its thermo-structural load carrying capacity using finite element analysis. The FEA studies indicated that HDPE attains minimal displacement and thermal stress. Besides, KI was identified as the best inhibitor material because of its high solubility to water and high melting point.

Tensile and flexural specimens have been fabricated from the selected HDPE polymer powder and their mechanical property was evaluated. The result showed that the HDPE parts fabricated by the developed SIS system achieved a tensile and flexural strength of 27.8 $\mathrm{MPa}$ and $34.59 \mathrm{MPa}$ respectively. Furthermore, the fabricated components have been found to have achieved good dimensional accuracy. Therefore, from these observations, it can be deduced that the indigenously designed and fabricated SIS system can be utilized to manufacture functional prototypes from various polymer powders of melting point up to $300^{\circ} \mathrm{C}$ for diverse applications. Furthermore, in this study the SIS process variable settings 
have been investigated only for HDPE polymer powder. In order to use the system for materials other than HDPE, a parametric study needs to be carried out to achieve optimum part quality. In addition, more optimization research needs to be conducted on the SIS process variables in order to enhance the quality of the fabricated parts. The developed SIS system has great potential for commercialization in the additive manufacturing sector in the near future.

\section{REFERENCES}

[1] Achillas C, Tzetzis D, Raimondo MO. (2017). Alternative production strategies based on the comparison of additive and traditional manufacturing technologies. International Journal of Production Research, 55(12):3497-3509. https://doi.org/10.1080/00207543.2017.1282645

[2] Gardan J. (2016). Additive manufacturing technologies: State of the art and trends. International Journal of Production Research, 54(10):3118-3132. https://doi.org/10.1080/00207543.2015.1115909.

[3] Abdulhameed O, Al-Ahmari A, Ameen W, Mian, SH. (2019). Additive manufacturing: Challenges, trends, and applications. Advances in Mechanical Engineering, 11(2):1-27. https://doi.org/10.1177/1687814018822880.

[4] Krassimir D. (2009). Rapid Prototyping and Engineering Applications: A Toolbox for Prototype Development. Assembly Automation. https://doi.org/10.1108/aa.2009.03329cae.001.

[5] Kruth, JP (1991). Material Incress Manufacturing by Rapid Prototyping Techniques. CIRP Annals - Manufacturing Technology, 40(2):603-614. https://doi.org/10.1016/S00078506(07)61136-6.

[6] Khoshnevis B, Asiabanpour B, Mojdeh M, Palmer K. (2003). SIS-a new SFF method based on powder sintering. Rapid Prototyping Journal, 9(1):30-36.

[7] Asiabanpour B, Palmer K, Khoshnevis B. (2004). An experimental study of surface quality and dimensional accuracy for selective inhibition of sintering. Rapid Prototyping Journal, 10(3):181-192.

[8] Asiabanpour B. (2003). An experimental study of factors affecting the selective inhibition of sintering process.

[9] Khoshnevis B, Yoozbashizadeh M, Chen Y. (2012). Metallic part fabrication using selective inhibition sintering (SIS). Rapid Prototyping Journal, 18(2):144-153. https://doi.org/10.1108/13552541211212122

[10] Asiabanpour B, Khoshnevis B, Palmer K. (2006). Advancements in the selective inhibition sintering process development. Virtual and Physical Prototyping, 1(1):43-52.

[11] Aravind A, Siddiqui TN, Arunkumar P, Balasubramanian E. (2017). Comparative Study of High Performance Polymers in Selective Inhibition Sintering Process through Finite Element Analysis. Polymers and Polymer Composites, 25(3):199-202. https://doi.org/10.1177/096739111702500303

[12] Petros M, Torabi P, Khoshnevis B. (2016). The influence of build strategies in selective inhibition sintering (SIS). International Journal of Advanced Manufacturing Technology, 84(5-8):969-979. https://doi.org/10.1007/s00170-015-7766-y

[13] Torabi P, Petros M, Khoshnevis B. (2014). Selective inhibition sintering: the process for consumer metal additive manufacturing. 3D Printing and Additive Manufacturing, 1(3):152155 .

[14] Asiabanpour B, Khoshnevis B, Palmer K, Mojdeh M. (2003). Advancements in the SIS process. 14th International Symposium on Solid Freeform Fabrication, Austin, TX.

[15] Palmer K., Khoshnevis B. (2003). Performance Factors in the Selective Inhibition of Sintering Process. IIE Annual Conference. Proceedings, 1. Institute of Industrial and Systems Engineers (IISE).

[16] Balasubramanian E, Rajamani D, Arunkumar P. (2018). Investigation on dry sliding wear behavior of Selective Inhibition Sintered HDPE parts using simulated annealing algorithm. Materials Today: Proceedings, 5(2):6534-6542. https://doi.org/10.1016/j.matpr.2017.11.308 
[17] Baligidad SM, Chandrasekhar U, Elangovan K, Shankar S. (2018). Taguchi's Approach: Design optimization of process parameters in selective inhibition sintering. Materials Today: Proceedings, 5(2):4778-4786. https://doi.org/10.1016/j.matpr.2017.12.051

[18] Yoozbashizadeh M, Khoshnevis B (2019). The Effects of Sintering Conditions on Selective Inhibition Sintering Process for Bronze. 3D Printing and Additive Manufacturing, 6(5):262271.

[19] Rajamani D, Balasubramanian E, Arunkumar P, Silambarasan M, Bhuvaneshwaran G. (2018). Experimental Investigations and Parametric Optimization of Process Parameters on Shrinkage Characteristics of Selective Inhibition Sintered High Density Polyethylene Parts. Experimental Techniques, 42(6):631-644. https://doi.org/10.1007/s40799-018-0286-6

[20] Rajamani D, Ziout A, Balasubramanian E, Velu R, Sachin S, Mohamed H. (2018). Prediction and analysis of surface roughness in selective inhibition sintered high-density polyethylene parts: A parametric approach using response surface methodology-grey relational analysis. Advances in Mechanical Engineering, 10(12). 168781401882099. https://doi.org/10.1177/1687814018820994

[21] Bhuvaneshwaran G, Sisay M, Manivannan R, Arunkumar P, Silambarasan M. (2019). Development of inhibition system for SIS process. Lecture Notes in Mechanical Engineering, 383-389. https://doi.org/10.1007/978-981-13-2697-4_42

[22] Shaikh H, Anis A, Poulose AM, Alam M, A-Otaibi MN, Alam MA, Al-Zahrani SM. (2016). Studies on High Density Polyethylene Reinforced with Phosphate Ore Particles: Thermal, Rheological, Mechanical and Morphological Properties. Polymer-Plastics Technology and Engineering, 55(17):1831-1841. https://doi.org/10.1080/03602559.2016.1171875

[23] Esakki B. (2017). Modeling and prediction of optimal process parameters in wear behaviour of selective inhibition sintered high density polyethylene parts. Progress in Additive Manufacturing. https://doi.org/10.1007/s40964-017-0033-z

[24] ASTM D638-14. (2014). Standard Test Method for Tensile Properties of Plastics. ASTM International, West Conshohocken, PA, 82(C):1-15.

[25] ASTM D790-03. (2017). Standard Test Methods for Flexural Properties of Unreinforced and Reinforced Plastics and Electrical Insulating Materials. ASTM International, West Conshohocken, PA.

[26] Shubham P, Sikidar A, Chand T. (2016). The influence of layer thickness on mechanical properties of the 3D printed ABS polymer by fused deposition modeling. Key Engineering Materials, 706:63-67. https://doi.org/10.4028/www.scientific.net/KEM.706.6

[27] Khalil Y, Kowalski A, Hopkinson N. (2016). Influence of energy density on flexural properties of laser-sintered UHMWPE. Additive Manufacturing, 10:67-75. https://doi.org/10.1016/j.addma.2016.03.002

[28] Şimşek B, İç, YT, Şimşek EH. (2016). A RSM-Based Multi-Response Optimization Application for Determining Optimal Mix Proportions of Standard Ready-Mixed Concrete. Arabian Journal for Science and Engineering, 41(4):1435-1450. https://doi.org/10.1007/s13369-015-1987-0 